\section{ECONOMICS}

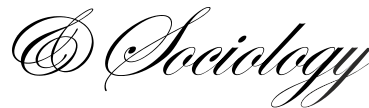

\title{
THE USE OF MOBILE PHONES BY CUSTOMERS IN RETAIL STORES: A CASE OF POLAND
}

\begin{abstract}
Companies wishing to meet customers' needs should always take into account new technological solutions, which are increasingly used by consumers. One of these technologies, which has become increasingly advanced, is the cell phone, particularly the so-called smartphone. Mobile phones have become a useful tool for both retail stores and customers. Customers can quickly search in their cells for the price of the product offered on websites. These broad capabilities of cell phones have led to a new kind of competition for traditional stores. On the other hand retail stores can use cell phones in order to inform their customers about new promotions, events, etc. The main objective of this paper is to introduce the scale and the cause of the use of cell phones by customers in traditional retailing. The author has focused on cell phone utilization by customers while shopping. In the paper the survey results have been presented, which had been conducted among cell phone users in one medium-sized Polish city. The research results show that cell telephony while shopping has yet to reach the same level of popularity among Polish customers, which it has attained in other countries.
\end{abstract}

JEL Classification: O31, M30, M37

Keywords: mobile technology, innovation, mobile telephony; consumer research; mobile advertising.

\section{Introduction}

The development of modern technology has created new opportunities for the retail sector. One of these technologies which has developed considerably is the mobile phone.

In the past, mobile phones were used only for communication among people. Currently there are advanced devices for users with not only a phone function but also with other applications which allow users to access sources of information (Internet, radio, ebook), sources of entertainment (games, music), calendar, etc. Increasingly, it is also a tool for business transactions, so-called: m-commerce. The popularity of mobile phones around the world, as well as their more modern functions, is a challenge for many companies in the field of customer service. A phone became a tool used in both traditional and electronic retailing. According to the report „The I Factor. How consumer demand is driving retail innovation” 
(the Economist, 2012) by 2020, trade with the use of mobile devices will be dominated either by offering a Near Field Communication and by the use of geographic positioning.

Although the use of mobile phones in the shopping process is increasing, there is no research focused on this subject in Poland. The only research which was undertaken covers the general aspects of using mobile phones.

The main aim of the article is to answer the question: Why and to what extent do retail customers use mobile phones in traditional retailing? Do the extent of mobile phones' application depend on age and gender? Why should retail stores implement this kind of solution in the field of customer service? In order to answer the question the author decided to conduct a survey among a group of mobile phone users in one medium-sized city in Poland. The survey was carried out between August and October 2012. The research conducted by the author shows that the use of mobile phones by the Polish respondents in traditional retailing has not taken off to the same extent as it has in the US and Western European countries. The most popular way of utilizing mobile phone in-store is a phone call to a close friend in order to obtain advice. The study shows that surveyed men more often than women search the Internet by mobile phones for the features of the product while shopping. According to the research, men will be also more likely than women to utilize mobile phone in-store in the future.

The paper is organized as follows. The first section presents the theoretical framework of the literature review and the background of mobile phone use in retail stores. The second section introduces the research methodology and survey results. The survey results were divided into five thematic areas, such as: utilization of mobile phones in-store, barcodes and QR codes scanning by mobile phone in a retail store, payments via mobile phones, mobile advertising and future use of mobile phones in-store. The final part of the paper presents the conclusion.

\section{Literature review and the background of mobile phone use in the retail stores}

The development of mobile telephony was quite rapid in the late 90s. Nowadays, mobile phones are not only a tool for communicating with another person but are mainly multi-functional devices to enable both entertainment and work. A breakthrough in the use of mobile phones for purposes other than voice communication came in 1996, when the Palm OS operating system was launched, which allowed the sending of e-mails on a cell phone. Later, in 2000, a new software was invented, "Pocket PC 2000" for Windows on Smart Phone, containing most of the features of the computer. Since then smart phones have experienced rapid growth. Companies started to see great opportunities for cell phones, especially smart phones, using them to enhance the work of warehouse staff, dealers and truck drivers.

New opportunities posed by mobile telephony were also noted by retailers. The use of mobile devices for retail stores is associated with so called mobile commerce (m-commerce). In the literature there are many definitions of m-commerce, most of which relate to $\mathrm{m}$ commerce as any business transaction executed by a wireless telecommunications network (Clarke, 2001, Yang, 2004) or any communication service via the Internet using mobile phone devices (Yazdanifard, Elkhabir, 2011). According to several authors (Coursaris, Hassanein, 2002; Kwon, Sadeh, 2004; Patil, Keota, 2012, Alqahtani, Goodwin, 2012; Jahanshahi, Mirzaie, Asadollahi, 2011) m-commerce has developed in a natural way from the area of electronic commerce, in which mobile devices play an important role. It should be emphasized that $\mathrm{m}$-commerce relates to transactions provided through all mobile devices, that is, also laptops or handheld terminals (Veijalainen, Terziyan, Tirri, 2006). It is worth noting that the principal mobile devices used in m-commerce by consumers are mobile phones, 
smartphones and palmtops. Ngai and Gunasekaran on the basis of review of 149 journal papers in the field of m-commerce, published in 2000-2003, a classification of articles into five thematic categories: "m-commerce theory and research, wireless network infrastructure, mobile middleware, wireless user infrastructure, and m-commerce applications and cases". (Ngai, Gunasekaran, 2007). Another literature review was done by AlHinai, Kurnia, Smith where the authors selected 100 journal papers for the period between 2003-2010. They limited their research to three areas: mobile, adoption and individual (AlHinai, Kurnia, Smith, 2010). In the Polish literature, despite the fact that e-commerce is already quite popular, there is a lack of scientific articles on the use of mobile phones in business (particularly in retail). It follows that it is quite a new subject, not yet very popular in Poland.

On the basis of the studied literature there are some applications which are used in mcommerce, such as: mobile banking (including payments), entertainment, information services, marketing, shopping, ticketing and telematics services. Figure 1 shows the applications used in m-commerce. Among the applications used by consumers in $\mathrm{m}$ commerce there are some applications, which should be particularly emphasized: $\mathrm{m}$-shopping, which enables the purchase by cell phone; m-pay, which allows making the payments using a cell phone; m-marketing - which enables contact with customers, pre- during- and after-sale; m-information system - which allows obtaining information on products, such as other users' reviews, prices, etc.

In the majority of studied articles, m-commerce applications only apply to ecommerce using mobile phones. Increasingly, however, empirical studies can be found on the use of mobile phones while shopping.

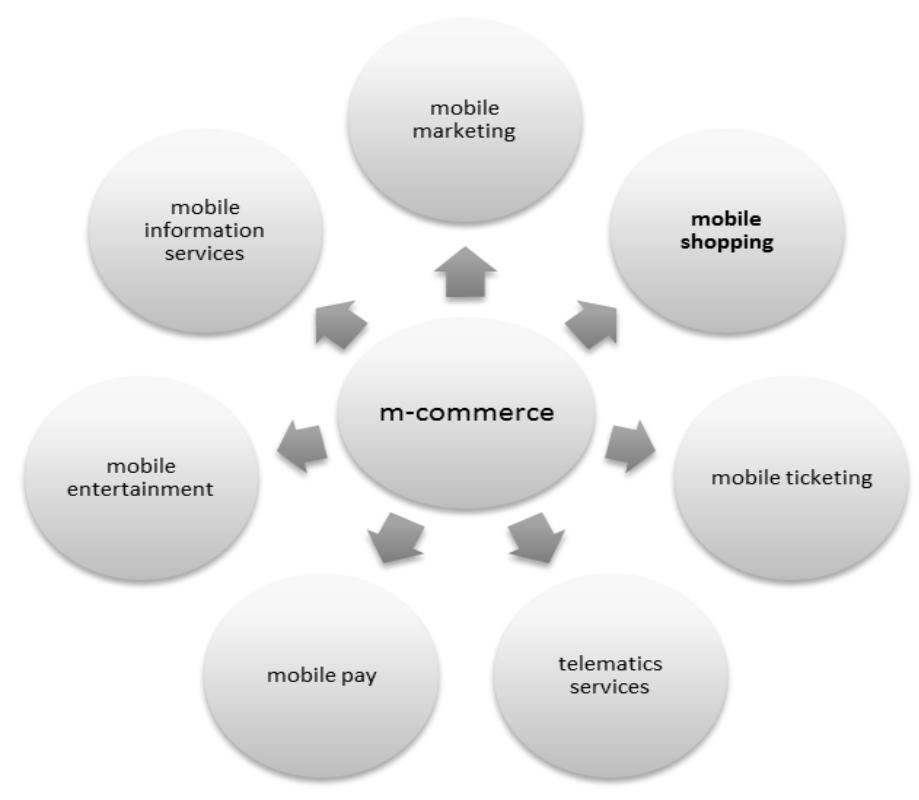

Figure 1. M-commerce applications

Source: Own work based on Rajnish Tiwari, Stephan Buse and Cornelius Herstatt, From electronic to mobile commerce, Opportunities through technology convergence for business services, TECH MONITOR, Special Feature: Converging Technologies, Sep-Oct 2006, pp. 38-45.

In the United States, as well as the United Kingdom, nationwide studies have been implemented on the use of cell phones, including while shopping in stores (U.S. Digital Future in Focus 2012; 2012 Mobile Future in Focus). In Poland every year a survey on the Information 
Society is carried out by the Ministry of Administration and Digitization, which, however, mainly concerns the use of computers and the Internet in professional and personal lives. In 2011 studies on the broad use of cell phones by consumers were conducted in Poland (Rejzerewicz, 2011; Telecommunications market in Poland in 2011). These studies present the results of the research on the use of cell phone users. However, a very small number (only for m-pay and m-marketing) raise issues related to the use of cell phones while shopping. Table 1 presents the selected literature which relates to the use of mobile phones while shopping. The articles are divided into four thematic categories (research): mobile advertisement (the use of cell phones by retailers), wireless localization technology, the use of cell phones by customers while shopping and m-payment. It can be seen that in both the international and Polish literature the issue of the use of cell phones in-store only has been addressed only by professional research companies or government institutions. In the Polish literature, the author has found no published studies showing the use of cell phones while shopping.

Table 1. The approach to the literature reviews of the utilization of cell phone in traditional retailing

Concepts in literature reviews of the utilization of mobile telephony in traditional retailing

Mobile advertisement (sending messages on customers' mobiles about sales, promotions; Bluetooth marketing)
Authors

Kavassalis, P.; Spyropoulou, N.; Drossos, D.; Mitrokostas, E.; Gikas, G.; and Hatzistamatiou, A. 2003; Melody M. Tsang, Shu-Chun Ho, and TingPeng Liang, 2004; Rettie, Grandcolas, \& Deakins, 2005; Merisavo, Kajalo, Karjaluoto, Virtanen, Salmenkivi, Raulas, Leppäniemi, 2010, Mobile Future in Focus, 2012, Report LJS Strategic Research, 2012 Halim, 2008; Fawaz, Hojaij, Kobeissi 2011; Rejzerewicz, 2012.

Mobile application which enable the finding of an item or a shop in the retailing center (via RFID) - wireless technology Aungst \&Wilson, 2005; Malladi \& Agrawal, 2002; Wen \& Mahatanankoon, 2004; Banerjee, Dholakia 2008;

The use of cell phones by customers while shopping:

- searching for the price in other shops (in Smith 2012, Mobile Future in Focus, 2012, Report CMB Consumer Pulse, 2011, On Device Research, May, 2012; Report LJS Strategic Research, 2012

Internet),

- shopping list,

- call to a friend,

- searching Internet for a review,

- checking the website of the shop,

- scanning barcodes,

- scanning QR codes

Mobile payments while shopping

Chen, 2008, Report CMB Consumer Pulse, 2011;

Tiwari, Buse and Herstatt, 2006, Veijalainen1,

Terziyan, Tirri, 2011; Paul Killoran, Fearghal

Morgan, Michael Schukat, 2005

Source: Own work.

On the basis of selected scientific articles the author has developed a list of fields of $\mathrm{m}$-commerce in traditional retailing, including an initiator of mobile phone use (Table 2). The initiative of Bluetooth marketing belongs mainly to the store but if a customer does not switch 
on Bluetooth in his or her cell phone, than this form of marketing does not work. The most popular way of mobile marketing in Poland is sending messages on customers' mobiles about sales, promotions etc. There are also many ways of utilizing cell phones by customers, such as: searching for the price in other stores, shopping list on mobile, calling a friend, scanning barcodes or QR codes, etc.

Table 2. Impact of mobile telephony in traditional retailing

\begin{tabular}{|c|c|c|c|}
\hline \multirow{2}{*}{ Fields of m-commerce in traditional retailing } & \multicolumn{3}{|c|}{ Initiator } \\
\hline & Store & Customer & Both \\
\hline Bluetooth marketing & & & $\mathrm{v}$ \\
\hline $\begin{array}{l}\text { Sending message on customers cell phones about } \\
\text { sales, promotions }\end{array}$ & $\mathrm{v}$ & & \\
\hline $\begin{array}{l}\text { Mobile application which enable the finding of an } \\
\text { item or a store in the retailing center (via RFID) }\end{array}$ & & & $\mathrm{v}$ \\
\hline Searching for the price in other stores (in Internet) & & $\mathrm{v}$ & \\
\hline Shopping list & & $\mathrm{V}$ & \\
\hline Call to a friend & & $\mathrm{v}$ & \\
\hline Searching Internet for a review & & $\mathrm{v}$ & \\
\hline Checking the website of the shop & & $\mathrm{v}$ & \\
\hline Scanning barcodes & & $\mathrm{V}$ & \\
\hline Scanning QR codes & & $\mathrm{v}$ & \\
\hline Paying for goods in a shop & & & $\mathrm{v}$ \\
\hline
\end{tabular}

Source: own study.

The popularity of modern cell phones among consumers has increased in a very dynamic way. By the end of 2012, the percentage of people with smart phones had increased to $40 \%$ from $14 \%$ in 2010 . It is little wonder that retailers have noticed a huge potential in mobile marketing, enabling the acquisition of new customers and maintaining those already acquired. Thanks to modern technology, more and more telecommunications companies are beginning to explore the individual consumer preferences during the purchasing process.

The purchasing process can be divided into three main stages: before the client decides to come to the store (before the transaction), when he or she visits the shop (this step may result in the transaction), and after a visit to the store (when the transaction takes place). There are three main stakeholders who use cell phones in the shopping process: consumer, retail stores and supporting actors, without whom mobile phone implementation in the shopping process would not be possible, such as: telecommunication companies, mobile phones and applications producers, Internet providers, banks, etc. Given the subject matter of the article the author would like to focus on the two main stakeholders: consumers and retail stores. During the pre-transactional purchasing process mobile phones are used mainly by consumers in order to gain information on the product they wish to purchase, stores, prices, etc. On the other hand, retail stores at this stage, send messages to mobile phones of potential customers about new promotions, sales, etc. During the visit to the store, consumers can use this tool for different purposes, ranging from dialing to friends and family asking for an opinion on a product, checking prices and reviews of the product on the Internet, and ending with payments made by a contactless card located on a phone. When a customer visits the store a Bluetooth system can be used to transmit information on the current offer of the store. The use of phones in the shopping process does not end with the transaction. Often, in a later stage, after the purchase mobile phones are used to deal with complaints and grievances by 
customers. From the trading companies at this stage phones are used to send information about promotions and attractive offers.

For the purposes of this paper the author has focused on the use of mobile phones by customers while shopping. Technological development in the field of mobile telephony made it necessary for retailers to implement new business models of customer service strategy, which should include mobile phone solutions (Figure 2). In the future, retail stores, which will want to be competitive with other stores (the traditional and virtual) will be forced to use modern technologies, such as mobile phones, in their relationship with customers. Mobile phones will be the most important tool in the retailer - customer relationship. With a variety of applications on cell phones, customers will be kept informed about special offers, new products and events. In addition, they will be able to scan bar codes and pay for purchases via mobile phones. Finally the retailers will be able to personalize their offer knowing individual needs of customers.

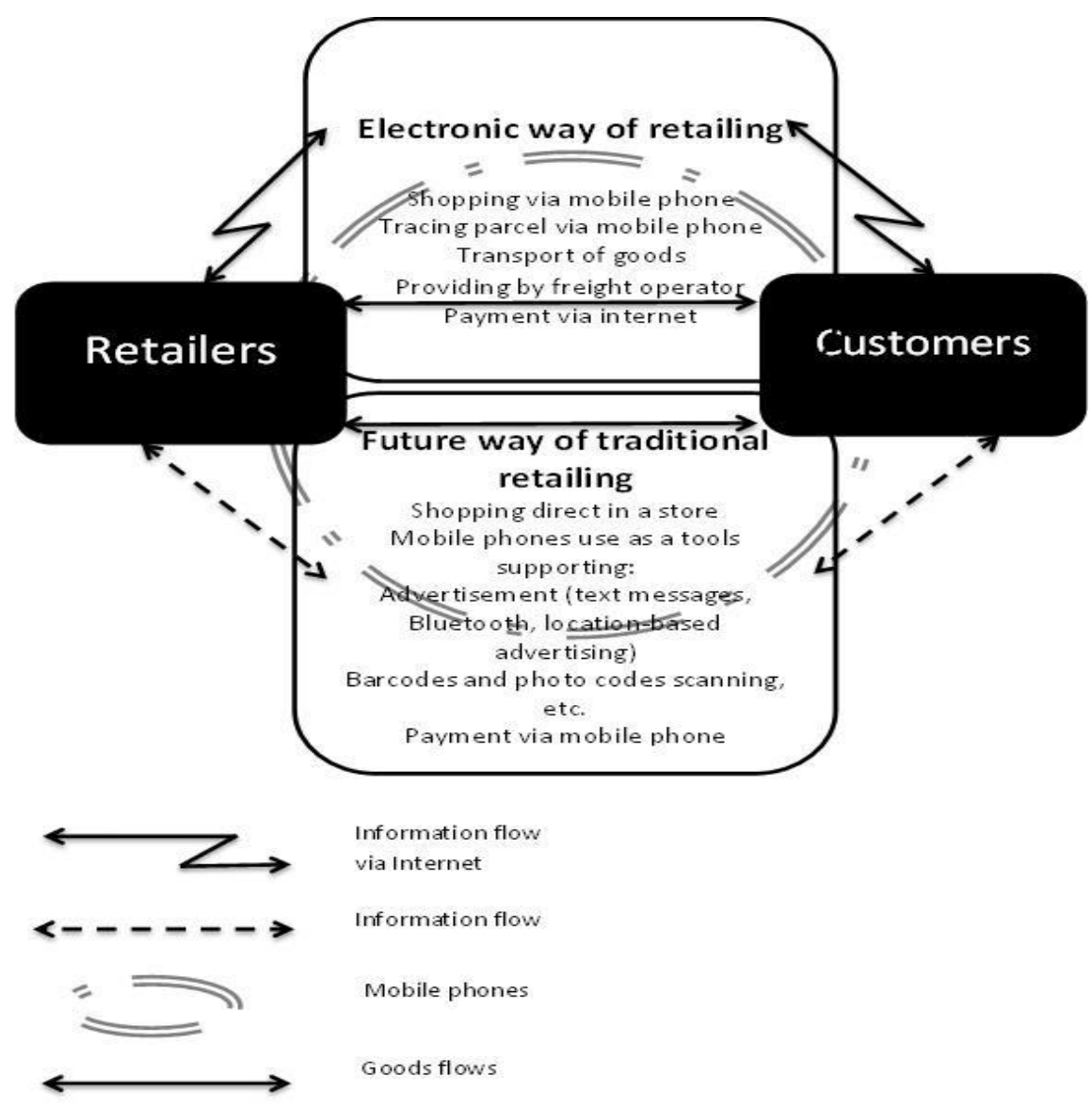

Figure 2. New business model for customer service in retailing Source: own study.

\section{The research methodology and survey results}

The author has developed five steps to implement the study. The first stage of the research process was a literature review. The author has analyzed the domestic and foreign literature in the field of $\mathrm{m}$-commerce. On the basis of an analysis of the literature the research tool has been developed in the form of a questionnaire. The questionnaire was sent to five experts for the test. After testing the survey the final versions of the questionnaire was developed. In order to achieve the aim of the research the author has conducted a survey among cell phone users in one medium-sized Polish city. 
The study was carried out between August and October 2012. For the study a sample of 408 people was selected. The sample was a stratified quota sample selected with the following criteria: gender and age (limited to the 18 to 45 age group, which, according to a study conducted by ComScore, in the US and selected EU countries, constitutes a group of people benefiting most frequently from smartphones) (Mobile Future in Focus 2012; How Smartphones Are Changing, 2011). The questionnaire was developed in Polish on the basis of such reports as: Smith, 2012, Mobile Future in Focus, 2012, Report CMB Consumer Pulse, 2011, On Device Research, 2012; Report LJS Strategic Research, 2012. The survey consisted of nine questions, the majority of them closed. The questions were focused on the use of mobile phones while shopping in the store. The whole questionnaire was divided into the following areas: Utilization of Mobile Phones in-store, Scanning by mobile phones barcodes and QR codes in retailing store, Payments via mobile phones, Mobile advertising and Future use of mobile phones in-stores (attached survey).

In order to conduct the survey the author has used two methods: online and face-toface interviews using a questionnaire survey. In order to distribute surveys on the Internet the author used the program for creating polls: www.ankietka.pl. Surveys were conducted in Polish by trained interviewers. The next stage of the research was to analyze the data. For this purpose, the author used SPSS. Obtained results allowed the drawing of conclusions and further recommendations.

\section{Utilization of mobile phones in-store}

The purpose of the survey was to elicit the views of respondents on the use of mobile phones while shopping. The first question concerned the use of mobile phones by the respondents while shopping in the store (Figure 3).

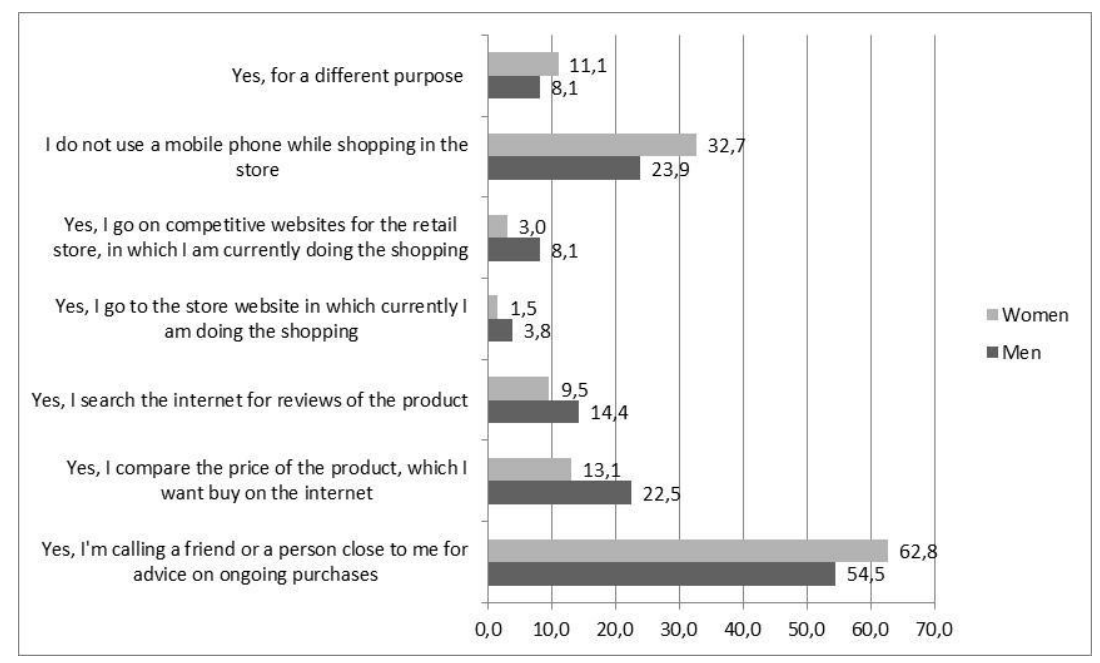

Figure 3. Number of respondents using mobile phones while shopping (multiple answers possible)

Source: own study.

Among all respondents, over $60 \%$ of women and nearly $55 \%$ of man dialed from a mobile phone to a friend (close person), to ask for advice while shopping. At the same time more women $(32.7 \%)$ than men $(23.9 \%)$ do not use mobile phones in-store at all. Research shows that male respondents were more likely than women to reach for the mobile phone in the shop in order to: compare the price of the product on the Internet $(22.5 \%$ of men, $13.1 \%$ of women); search the Internet for reviews of the product (14.4\% men; $9.5 \%$ women); or go 
on competitive websites for the retail store (3.8\% of men, $1.5 \%$ of women). Approximately $10 \%$ of respondents use a mobile phone while shopping for another purpose, such as: to take and send pictures, to read the shopping list, to use a calculator, etc. However using mobile phones for other purpose than a call remains unpopular among Polish respondents.

\section{Barcodes and QR codes scanning by mobile phones of in retailing store}

The next group of questions was devoted to barcode scanning. Among the respondents, barcode and photo code scanning remain unpopular. There are only two male respondents who scan barcodes every day. At the same time none of the respondents scans photo codes every day. Less than $4 \%$ of respondents scan barcodes or photo codes once a week and almost $8 \%$ of respondents at least once a month (Figures 4 and 5). Over 90\% of female respondents say they do not scan the barcode or QR code by a mobile phone in the shop. At the same time approximately $70 \%$ of men respondents do not use a mobile scanner while shopping. However, men are keener on scanning barcodes and photo codes than women. There is little differences between age groups on this issue.

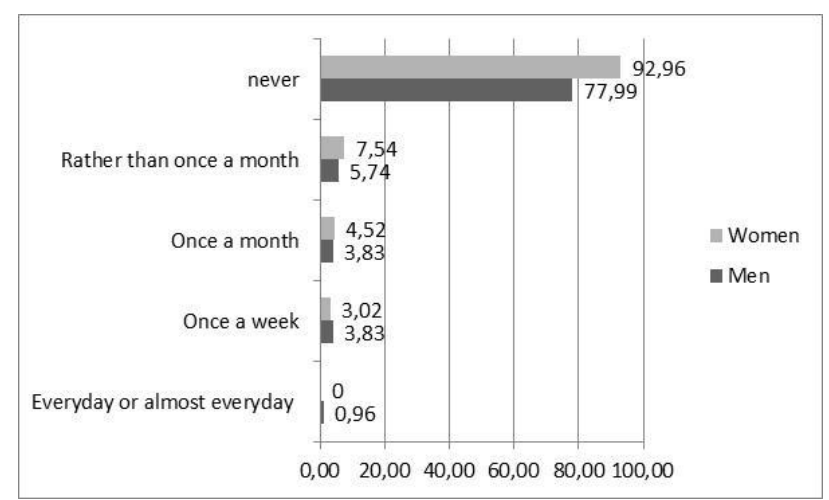

Figure 4. Percentage of respondents scanning barcodes by mobile phone while shopping Source: own study.

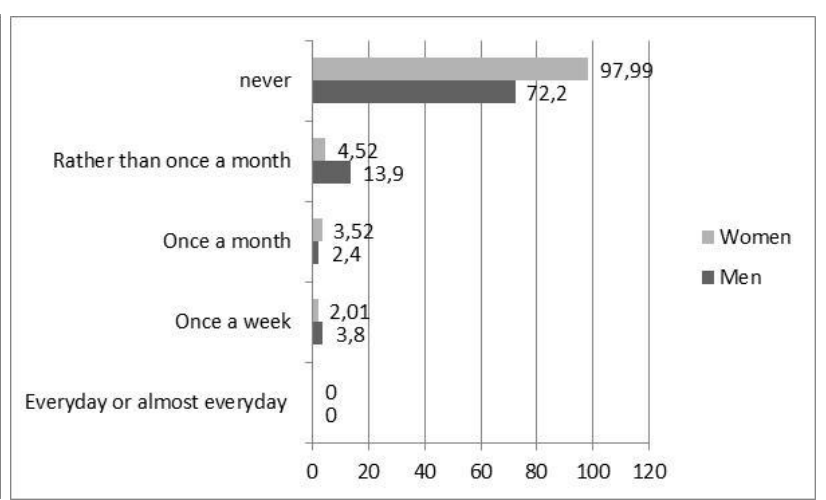

Figure 5. Percentage of respondents scanning QR codes by mobile phone while shopping

Source: own study.

During the study, respondents were also asked about the implementation of micropayments using a mobile phone (Figure 6).

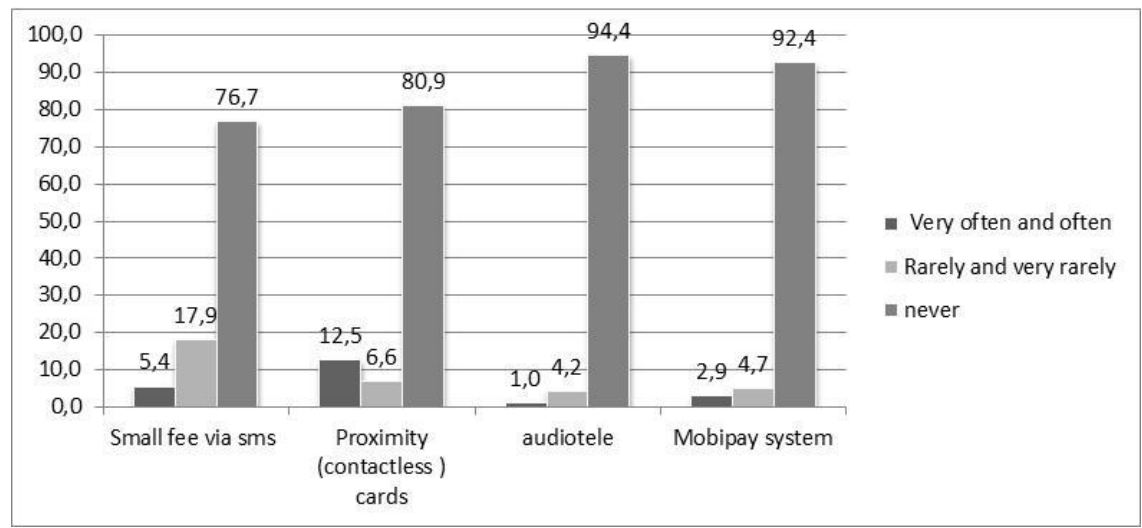

Figure 6. Percentage of respondents who make micropayments by mobile phone Source: own study. 
Over $75 \%$ of respondents stated that they had never made small payments via SMS. Only $5.4 \%$ of respondents performed such payment very often and often and over $17 \%$ of respondents rarely or very rarely. Payments using contactless cards are also highly unpopular among respondents. It is obviously because such methods of making payment arrived in Poland relatively recently. Over $80 \%$ of respondents have never used such a payment method and $12 \%$ do it every day. The two least popular methods of payment via mobile phone among respondents are: audiotele and mobipay system. Over $90 \%$ of respondents have never used either of these forms of payment.

\section{Mobile advertising}

Mobile advertising is the new direction of marketing activities of many retailers. New technological capabilities of mobile phones not only allow the sending of messages, but also use the Bluetooth system to transmit information about the new store offers, new products, promotional campaigns, sales, etc. During the study respondents were asked to express their opinion on the store marketing activities by sending messages to the consumers' mobile phones. Research shows that female respondents are far more susceptible to this kind of advertising. According to 66 of the women (and 38 men) messages sent by stores sometimes encourage them to make purchases. Still, a large proportion of respondents (107 male respondents and 91 female respondents) believe that these kinds of marketing activities do not encourage them to make purchases in the store.

Mobile marketing is the way of the future, becoming more important in satisfying the needs of customers. There are stores that send messages via Bluetooth to the customers while shopping in the store. Over $2 \%$ of female respondents and over $4 \%$ of male respondents always pay attention to such messages and take into account the information sent by Bluetooth (Figure 7). More than 3\% of female and over $4 \%$ of male respondents claim that they are interested in messages. For almost $20 \%$ of male respondents and only $8 \%$ of female respondents Bluetooth messages are not important, or even annoyed them. The largest group of respondents does not use the function of transferring information while shopping. An interesting fact is that more female respondents (almost 90\%) than male respondents (over $60 \%$ ) do not use such a tool while shopping. Those figures show that men are more likely to use [ ] new technological solution in their mobile phones than women.

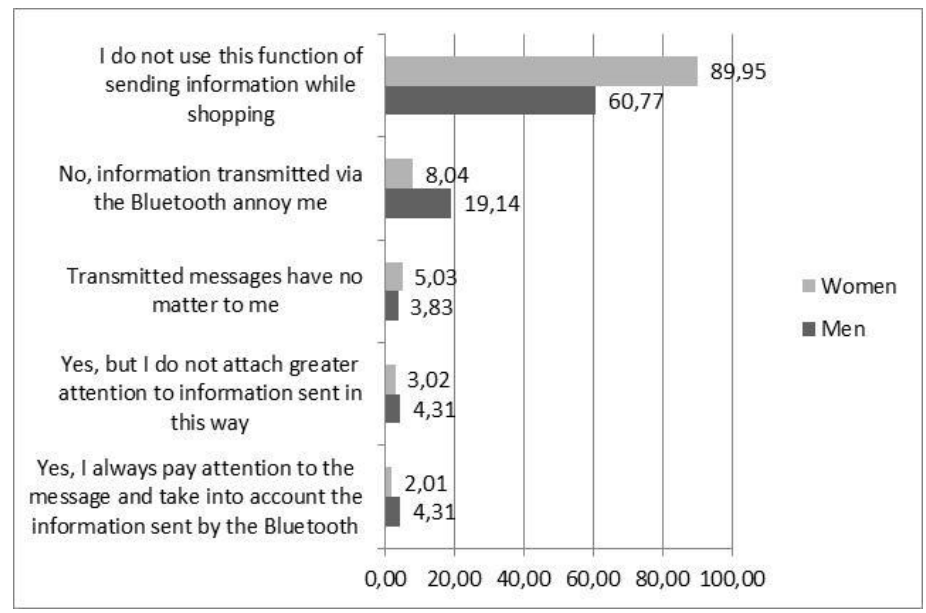

Figure 7. The interest of the respondents in the Bluetooth messages received from retailers while shopping

Source: own study. 


\section{Future use of mobile phones in-store}

The use of mobile phone in Polish retail stores remains relatively unpopular. Some consumers need a more time to switch to the new technology. In the future, however, a large proportion of the respondents will be interested in the use of mobile phones while shopping (Figure 8). While currently more male respondents use mobile phones while shopping, the survey shows that in the future more female respondents (almost 50\%) than men (40\%) will be interested in scanning barcodes to obtain information about the price of the product while shopping. At the same time almost $40 \%$ of female respondents are not interested in using mobile phone while shopping compared to $22.9 \%$ of male respondents. Nearly $30 \%$ of respondents (both female and male) also said that in the future they would like to scan photo codes to get more information about a particular product / service and pay for goods in a shop with a mobile phone.

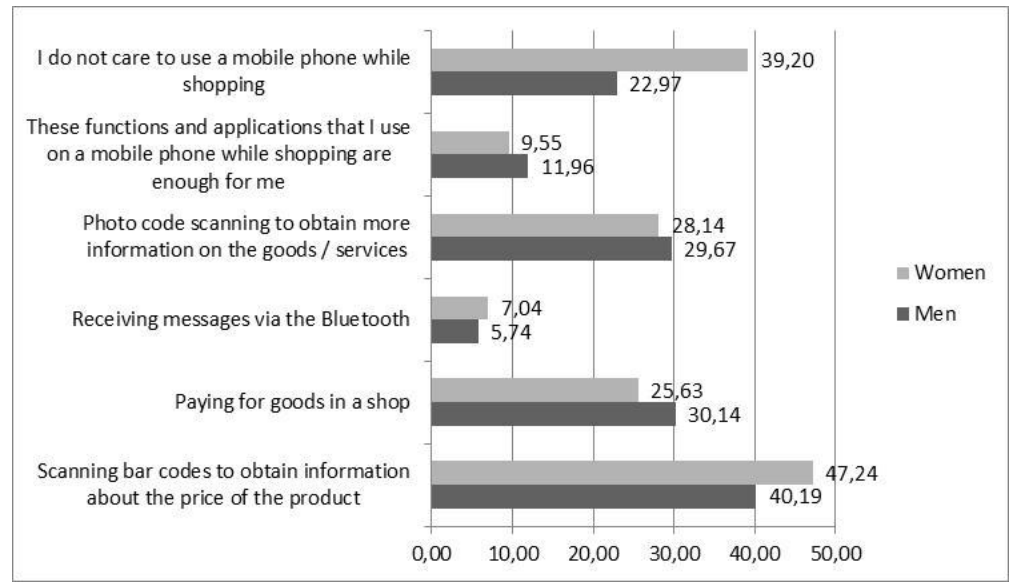

Figure 8. Respondents' opinions about the possibility of using mobile phones while shopping in the future $(\%)$

Source: own study.

\section{The coefficient of the convergence}

In order to determine the strength of the correlation between selected factors the Czuprow convergence coefficient has been calculated. The convergence of the variables can been used in terms of a large collectivity or a random sample, $\mathrm{n} \geq 30$ (the contingency table) ${ }^{1}$. We are dealing with stochastic contingency when the conditional distribution of one variable depends on the values taken by the other variable. If the conditional distributions are identical then we are dealing with stochastic independence, if for every $i, j$ there occurs the equation:

$$
\mathbf{f}_{\mathbf{i j}}=\mathbf{f}_{\mathbf{i}} * \mathbf{f}_{\mathbf{j}}
$$

for $\mathrm{i}=1,2, \ldots, \mathrm{k}$ (the number of rows in the contingency table), $j=1,2, \ldots, 1$ (the number of rows in the contingency table).

\footnotetext{
1 Zielińska, A., Sej-Kolasa, M. (2004), Excel $w$ statystyce, materiały do ćwiczeń, Wydawnictwo Akademii Ekonomicznej im. Oskara Langego we Wrocławiu, Wrocław, s. 60-61; Zielińska, A., Becla, A. (2003), Elementy statystyki i metod ilościowych. Dla studentów administracji publicznej, socjologii i ekonomii, Wydawnictwo IBis, Wrocław, s. 80-81.
} 
On the other hand, stochastic contingency occurs when there is one such conditional distribution, for which the above equation does not happen:

$$
\mathbf{f}_{\mathbf{i j}} \neq \mathbf{f}_{\mathbf{i}} * \mathbf{f}_{\mathbf{j}}
$$

There are many measures related to stochastic contingency. For the purposes of further analysis stochastic contingency determined by the Czuprow convergence coefficient will be described ( $\left.\mathbf{T}_{\mathbf{X Y}}, \mathbf{T}_{\mathbf{Y X}}\right)$.

$$
\mathbf{T}_{\mathbf{X Y}}=\mathbf{T}_{\mathrm{YX}}=\sqrt{\frac{\sum_{\mathbf{i}=1 \mathbf{j}=1}^{\mathbf{k}} \frac{\mathbf{l}\left(\mathbf{f}_{\mathbf{i j}}-\mathbf{f}_{\mathbf{i}} * \mathbf{f}_{\mathbf{j}}\right)^{2}}{\mathbf{f}_{\mathbf{i}} * \mathbf{f}_{\mathbf{j}}}}{\min (\mathbf{k}, \mathbf{l})-1}}
$$

where min $(\mathrm{k}, \mathrm{l})$ it is the smallest number of rows and columns

if $\mathrm{T}=0$ means stochastic contingency between the characteristics of attributes, and

for $\mathrm{T}=1$ - functional dependence of two attributes, while the values of the intervals:

0-0,33 weak, insignificant stochastic correlation occurs between the attributes,

0,34-0,66 - average stochastic correlation occurs between the attributes,

0,67-1 - strong, significant stochastic correlation occurs between the attributes.

Correlations:

Table 2. Contingency between the question „How often do you scan barcodes by mobile phone while shopping?" and the age of the respondents

\begin{tabular}{cccc}
\hline \multirow{2}{*}{$\begin{array}{c}\text { How often do you scan barcodes by mobile } \\
\text { phone while shopping }\end{array}$} & below 30 & $\begin{array}{c}\text { Above } \\
30 \text { to } 45\end{array}$ & $\begin{array}{c}\text { The total number of } \\
\text { respondents related to the } \\
\text { question „How often do you } \\
\text { scan barcodes by mobile } \\
\text { phone while shopping?” }\end{array}$ \\
\hline Every day or almost every day & 0 & 0 & 0 \\
\hline Once a week & 6 & 10 & 16 \\
\hline Once a month & 8 & 9 & 17 \\
\hline Less than once a month & 14 & 13 & 27 \\
\hline Never & 170 & 178 & 348 \\
\hline The number of respondents in each age category & 198 & 210 & 408 \\
\hline
\end{tabular}

Source: own work.

$$
\mathbf{T}_{\mathbf{X Y}}=\mathbf{T}_{\mathbf{Y X}}=\mathbf{0 , 0 5}
$$

There is a slight, insignificant contingency between the question „How often do you scan barcodes by mobile phone while shopping?" and the age of the respondents. 
Table 3. Contingency between the question „How often do you scan barcodes while shopping in order to receive information about the price?” and the question ,Would you like to scan QR codes in the future in order to obtain more information on the goods / services?"

\begin{tabular}{cccc}
\hline $\begin{array}{c}\text { How often do you scan barcodes while } \\
\text { shopping in order to receive } \\
\text { information about the price? }\end{array}$ & $\begin{array}{c}\text { Would you like to scan QR } \\
\text { codes in the future in order } \\
\text { to obtain more information } \\
\text { on the goods / services? }\end{array}$ & $\begin{array}{c}\text { The total number of } \\
\text { respondents related to the } \\
\text { question „How often do you } \\
\text { in order to receive information } \\
\text { about the price?” }\end{array}$ \\
\hline Every day & 0 & 0 & 0 \\
\hline Once a week & 8 & 8 & 16 \\
\hline Once a month & 13 & 4 & 17 \\
\hline Less than once a month & 16 & 11 & 27 \\
\hline never & 254 & 94 & 408 \\
\hline $\begin{array}{c}\text { The total number of respondents } \\
\text { related to the question about the future } \\
\text { use of QR codes }\end{array}$ & 291 & 117 & \\
\hline
\end{tabular}

Source: own work.

$$
\mathbf{T}_{\mathrm{XY}}=\mathbf{T}_{\mathrm{YX}}=\mathbf{0 , 1 2}
$$

There is a slight, insignificant contingency between the question „How often do you scan barcodes while shopping in order to receive information about the price?" and the question „Would you like to scan photo codes in the future in order to obtain more information on the goods / services?"

Table 4. Contingency between the question „Are you encouraged to shop by mobile messages?" and the age of the respondents

\begin{tabular}{lcccccc}
\hline & \multicolumn{3}{l}{ Are you encouraged to shop by mobile messages? } & The number \\
\cline { 2 - 6 } Age of the respondents & $\begin{array}{c}\text { Yes, } \\
\text { always }\end{array}$ & $\begin{array}{c}\text { Yes, } \\
\text { sometimes }\end{array}$ & $\begin{array}{c}\text { Yes, } \\
\text { rarely }\end{array}$ & $\begin{array}{c}\text { Yes, } \\
\text { very } \\
\text { rarely }\end{array}$ & $\begin{array}{c}\text { No, sms do } \\
\text { not encourage } \\
\text { me to shop }\end{array}$ & $\begin{array}{c}\text { respondents } \\
\text { in each age } \\
\text { category }\end{array}$ \\
\hline Below 30 & 3 & 50 & 20 & 29 & 96 & 198 \\
\hline Above 30 to 45 & 4 & 54 & 24 & 26 & 102 & 210 \\
\hline $\begin{array}{l}\text { The total number of } \\
\text { respondents related to } \\
\text { the question ,Are you } \\
\text { encouraged to shop by } \\
\text { mobile messages?" }\end{array}$ & 7 & 104 & 44 & 55 & 198 & 408 \\
\hline
\end{tabular}

Source: own work.

$$
\mathbf{T}_{\mathrm{XY}}=\mathbf{T}_{\mathrm{YX}}=\mathbf{0 , 0 4}
$$

There is a slight, insignificant contingency between the question „Are you encouraged to shop by mobile messages?" and the age of respondents. 


\section{Conclusion}

In the paper the role of mobile telephony during the shopping process has been presented. The author has analyzed the literature related to the mobile telephony and introduced the research outputs. The results of the study show that mobile phones are not yet very popular among respondents. In addition there are differences in customers' preferences in terms of using mobile phone in-store. Female respondents are more traditional than men. Surveyed men more often than women utilized mobile phone for searching the Internet in order to compare the price of the product, read the reviews, information on competitive websites, while a majority of women called a friend in order to obtain some advice. Surprisingly, there is no correlation between the age of respondents and the extent of using mobile phones in the shop.

Information about customers' preferences in terms of using phones during shopping process maybe very useful for retail companies. Currently over $32 \%$ of retailers use mobile phones to communicate with the client and forecasts predict that by 2020 the number may rise to more than $40 \%$. In Poland, retail stores mainly use mobile phones to send text messages to their customers to inform them about news and promotions. Mobile phones (especially smartphones) are the ICT tools available to enhance customer service while shopping in the retail store. In addition this tool enables customers' preferences to be tracked while shopping. It is enough to have Wi-Fi on customers' mobile phones switched on. In the near future, mobile phones will be the primary tool for communication and customer relations. Therefore retail stores should include mobile phone technology into the customer service strategy. However, only the combined and consistent operation of all stakeholders can contribute to the greater dissemination and exploitation of mobile phones in retail stores.

The studies carried out by the author is merely the beginning of the research that could be carried out on a sample corresponding to the population of the country, enabling deeper analyzes of the convergence coefficient. In addition these studies should be supplemented by the survey conducted among retail stores.

\section{References}

AlHinai, Y. S., Kurnia, S., Smith, S. P. (2010), The adoption of mobile commerce services by individuals: A Current State of the Literature, 21st Australasian Conference on Information Systems, 1-3 Dec 2010, Brisbane, ACIS 2010 Proceedings, Association for Information Systems, AIS Electronic Library (AISeL).

Alqahtani, A. S., Goodwin, R. (2012), E-commerce Smartphone Application, (IJACSA) International Journal of Advanced Computer Science and Applications, Vol. 3, No. 8, pp. 54-59.

Arroyo-Cañada, F.-J., Gil-Lafuente, J. (2011), Influence Factors in Adopting the mCommerce, MOBILITY 2011: The First International Conference on Mobile Services, Resources, and Users, IARIA, pp. 46-50.

Asmahan Altaher (2012), M-Commerce service systems implementation, (IJACSA) International Journal of Advanced Computer Science and Applications, Vol. 3, No. 8, pp. 131-136.

Aungst, S. G., \& Wilson, D. T. (2005), A primer for navigating the shoals of applying wireless technology to marketing problems, The Journal of Business \& Industrial Marketing, 20(2/3), pp. 59-70.

Banerjee, S., Dholakia, R. R. (2008), Mobile advertising: Does location-based advertising work? International Journal of Mobile Marketing, December, Vol. 3, No 2, pp. 68-74. 
Banu, W. A., Khader, P. S. A., Shriram, R. (2012), Query Suggestion Generation Methods for Mobile Phones, Information Technology Journal 11 (8), pp. 1056-1062.

Barnes, S. J. (2002), The mobile commerce value chain: analysis and future developments, International Journal of Information Management 22, Pergamon, pp. 91-108.

Chang, Y. F., Chen, C.S., Zhou, H. (2009), Smart phone for mobile commerce, Computer Standards \& Interfaces 31, Elsevier, pp. 740-747.

Coursaris, C., Hassanein, K. (2002), Understanding m-commerce, Quarterly Journal of Electronic Commerce 3 (3), pp. 247-271.

Ferdous, Md. S. and Poet, R. (2012), Analysing Power Consumption Of Different Browsers \& Identity Management Systems In Mobile Phones, International Journal of Distributed and Parallel Systems (IJDPS) Vol. 3, No. 2, March, pp. 21-41.

Halim, Azni H. (2008), Bluetooth mobile advertising system using pull-based approach, Information Technology, ITSim 2008, Conference Publications, Volume 4, pp. 1-4.

iModerate Research Technologies (2011), How Smartphones Are Changing the Retail Shopping Experience, CMB Consumer Pulse.

Jahanshahi, A. A., Mirzaie, A., Asadollahi, A. (2011), Mobile Commerce Beyond Electronic Commerce: Issue And Challenges, Asian Journal of Business and Management Sciences, Vol. 1 No. 2, pp. 119-129.

Karcewicz, J. (2003), Bariery rozwoju e-commerce, Materiaty konferencyjne SWO, pp. 443448.

Kavassalis, P., Spyropoulou, N., Drossos, D., Mitrokostas, E., Gikas, G., and Hatzistamatiou, A. (2003), Mobile permission marketing: Framing the market inquiry, International Journal of Electronic Commerce, 8, 1, pp. 55-80.

Killoran, P., Morgan, F., Schukat, M. (2005), A New Secure Wireless Financial Transaction Architecture, Eurocon 2005, Serbia \& Montenegro, Belgrade, November 22-24, pp. 1060-1063.

Kwon, O.B., Sadeh, N. (2004), Applying case-based reasoning and multi-agent intelligent system to context-aware comparative shopping, Decision Support Systems 37 (2), pp. 199-213.

Malladi, R., \& Agrawal, D. P. (2002), Current and future applications of mobile and wireless networks, Communications of the ACM, 45(10), pp. 144-146.

Mallat, N., Rossi, M., Tuunainen, V., Öörni, A. (2009), The impact of use context on mobile services acceptance: The case of mobile ticketing, Information \& Management, Volume 46, Issue 3, Elsevier, pp. 190-195.

Merisavo, M., Kajalo, S., Karjaluoto, H., Virtanen, V., Salmenkivi, S., Raulas, M., Leppäniemi, M. (2007), An empirical study of the drivers of consumer acceptance of mobile advertising, Journal of Interactive Advertising, Vol. 7 No 2, pp. 41-50.

Mobile Future in Focus (2012), Key Insights from 2011 and What They Mean for the Coming Year, comScore.

Muthaiyah, S. (2004), Key Success Factors of 3rd Generation Mobile Network Services for M-Commerce in Malaysia, American Journal of Applied Sciences 1(4), pp. 261-265.

Ngai, E.W.T., Gunasekaran, A. (2007), A review for mobile commerce research and applications, Elsevier, Decision Support Systems 43, pp. 3-15.

On Device Research (2012), Mobile Phone Shopping Diaries An On Device Research study for the IAB.

Patil, U. V., Keote, M. L. (2012), A Review On Technologies For E-Commerce Access, International Journal of Engineering Science and Technology (IJEST), Vol. 4, No. 03, pp. 1066-1070. 
Ramalingam, A., Dorairaj, P. and Ramamoorthy, S. (2012), Personal Safety Triggering System On Android Mobile Platform, International Journal of Network Security \& Its Applications (IJNSA), Vol. 4, No. 4, pp. 179-197.

Rejzerewicz R. (2012), Marketing mobilny, Raport 2011/2012, Marketdog.pl, pp. 1-21.

Report LJS Strategic Research (2012), How Smart Phones are helping Create a New Generation of Smart Shoppers.

Rettie, R., Grandcolas, U. and Deakins, B. (2005), Text message advertising: Response rates and branding effects, Journal of Targeting, Measurement and Analysis for Marketing, 13(4), pp. 304-313.

Shapiro, O. (2012), How Smart Phones are helping Creating a New Generation of Smart Shoppers, Report LJS Strategic Research 2012.

Smith, A. (2012), The rise of in-store mobile commerce, Pew Research Center's Internet \& American Life Project.

Suki, N. M. (2011), A structural model of customer satisfaction and trust in vendors involved in mobile commerce, Int. Journal of Business Science and Applied Management, Volume 6, Issue 2, pp. 17-30.

The I Factor (2012), How Consumer Demand is Driving Retail Inovation The Economist Intelligence Unit Limited, the Economist, 2012, pp. 1-29.

Tiwari, R., Buse, S. and Herstatt, C. (2006), From electronic to mobile commerce, Opportunities through technology convergence for business services, Special Feature: Converging Technologies, TECH MONITOR, pp. 38-45.

Transaction Management for M-Commerce at a Mobile Terminal (1999), This research funded by the Finnish National Technology Agency (TEKES), Nokia Networks, HP Finland, and Yomi Solutions (contract 330/401/99).

Tsang, M. M., Ho, Sh.-Ch., and Liang, T.-P. (2004), Consumer Attitudes Toward Mobile Advertising: An Empirical Study, International Journal of Electronic Commerce, Vol. 8, No. 3, pp. 65-78.

Wen, H. J., \& Mahatanankoon, P. (2004). M-commerce operation modes and applications, International Journal of Electronic Business, 2(3), p. 301.

Wu, J.-H., Wang, S.-Ch., (2005), What drives mobile commerce? An empirical evaluation of the revised technology acceptance model, Information \& Management 42, Elsevier, pp. 719-729. 